\title{
Rekonstruksi Peran Perpustakaan dan Intervensi Pustakawan kepada Pemustaka ${ }^{1}$
}

\author{
Abdul Rahman Saleh \\ 1,2Perpustakaan IPB University \\ e-mail : abdulr.saleh.2003@gmail.com
}

\begin{abstract}
Abstrak
Pendahuluan. Dalam era teknologi informasi yang kemudian melahirkan teknologi disruptive perpustakaan menghadapi tantangan yang sangat berat. Banyak unit-unit usaha yang akhirnya gulung tikar atau setidaknya mengurangi karyawannya akibat teknologi disruptive ini. Sebagian pekerjaan mereka sudah digantikan oleh mesin atau robot. Perpustakaan harus "menciptakan" layanan-layanan baru agar tidak termakan oleh teknologi ini. Sebagian kerja perpustakaan sudah diambil alih oleh mesin, seperti transaksi peminjaman bahan perpustakaan pada perpustakaan konvensional dan bahkan perpustakaan digital saat ini sudah mulai beroperasi. Dengan perpustakaan digital maka pemustaka memang tidak perlu lagi mendatangi secara fisik perpustakaan sebab semua layanannya sudah dapat dilakukan melalui gawai. Kajian ini merupakan kajian literatur yang membahas tingkatan layanan atau mediasi menurut Kuhlthau untuk pemenuhan kebutuhan informasi pemustaka
\end{abstract}

Metode dan Pengumpulan Data. Literatur dikumpulkan dari akses ke internet dan koleksi cetak perpustakaan.

Analisis Data. Dari literatur yang dikumpulkan dibuatkan catatan poin penting yang kemudian dianalisis secara deskriptif.

Hasil dan Pembahasan. Kuhlthau memperkenalkan layanan informasi yang disebutnya sebagai intervensi kepada pemustaka. Menurut Kuhlthau ada dua layanan perpustakaan dasar di mana pustakawan profesional terlibat dalam intervensi tersebut yaitu referensi dan instruksi bibliografi. Layanan referensi adalah mediasi kepada pemustaka untuk membantu lokasi dan penggunaan sumber dan informasi. Mediasi seperti ini bisa mediasi sederhana, tetapi juga bisa mediasi yang panjang yang melibatkan proses pencarian informasi yang rumit dan sangat panjang. Konsep zona intervensi ditentukan oleh sifat masalah pemustaka dan tahapan proses pemustaka mengarah pada identifikasi tingkat mediasi dan pendidikan. Menurut Kuhlthau ada lima level mediasi yaitu: organizer (pengatur), locator (pencari lokasi), identifier (pengidentifikasi), advisor (penasihat), dan counselor (konselor). Jika pemustaka bisa bekerja sendiri dalam mencari informasi maka pustakawan tidak perlu melakukan intervensi untuk memediasi pemustaka tersebut. Namun jika pemustaka tidak mampu melakukan pencarian sendiri maka kehadiran pustakawan untuk mengintervensi yaitu memediasi pemustaka sangat diperlukan

Kesimpulan. Ada lima level mediasi menurut Kuhlthau yaitu: organizer (pengatur), locator (pencari lokasi), identifier (pengidentifikasi), advisor (penasihat), dan counselor (konselor).

Kata Kunci: Perubahan layanan perpustakaan; mediasi Kublthau; proses pencarian informasi.

\begin{abstract}
Introduction. In the era of information technology that causes the emergence of disruptive technology, libraries face very formidable challenges. Many businesses have gone bankrupt or at least reduced their employees due to this disruptive technology. Many of their jobs have been replaced by machines or robots. Libraries must develop new services so as not to be affected by this technology. Some libraries work has been taken over by machines, such as circulation of library materials and even digital libraries are now starting to operate. The concept of an intervention zone is determined by the nature of the user's problem and the stages of the user process leading to the identification of mediation and education levels. According to Kublthau, there are five levels of mediation, namely: organizer, locator, identifier, advisor, and counselor. If the user can work alone in finding information, then the librarian does not need to intervene to mediate the user. With a digital library, users no longer need to physically visit the library because all
\end{abstract}

${ }^{1}$ Dipresentasikan pada rapat Tim Revisi Permenpan 9 tahun 2014 di Perpustakaan Nasional. Jakarta, tanggal 25 Mei 2021. 
services can be done through devices. This study is a literature review that discusses the level of service or mediation according to Kublthau to meet the information needs of users.

Methods and Data Collection. The literature was collected from the internet and the library's print collection.

Data analysis. From the collected literature, notes of important points were made which were then analyzed descriptively.

Results and Discussion. Kublthau introduced an information service that he called intervention to users. According to Kublthau, there are two basic library services in which professional librarians are involved in the intervention, namely bibliographic reference and instruction. Reference services are mediation to users to assist with the location and use of resources and information. This kind of mediation can be a simple mediation, but it can also be a lengthy mediation that involves a complex and very lengthy information search process. The concept of an intervention zone is determined by the nature of the user's problem and the stages of the user process leading to the identification of mediation and education levels. According to Kublthau, there are five levels of mediation, namely: organizer, locator, identifier, advisor, and counselor. If the user can work alone in finding information, then the librarian does not need to intervene to mediate the user. However, if the user is not able to do the search on his own, then the presence of the librarian to intervene, namely mediating the user is very necessary

Conclusion. According to Kublthau, there are five levels of mediation, namely: organizer, locator, identifier, advisor, and counselor.

Keywords: Changes in library services; Kublthau mediation; information search process.

\section{Pendahuluan}

Perpustakaan dan pendidikan adalah dua entitas yang sulit dipisahkan. Pendidikan tanpa dukungan perpustakaan tentunya kurang berjalan dengan baik sebab bahan-bahan ajar dan bahan pengayaan dalam proses belajar mengajar biasanya disediakan oleh perpustakaan. Suatu hal yang sangat sulit dilakukan bahwa pembelajar (murid/mahasiswa bahkan masyarakat) mengumpulkan sendiri bahan ajar yang diperlukannya. Mungkin mereka bisa membeli bahan ajar yang menjadi kebutuhan pokoknya, namun tentunya dalam jumlah yang sangat terbatas baik dari segi kemampuan ekonomi maupun dari kemampuan menyimpan sebagai koleksi pribadi. Hal ini karena informasi atau literatur yang diproduksi sangatlah banyak. Apalagi dengan kemajuan teknologi digital seperti saat ini. Namun perpustakaan sesuai dengan tugasnya dapat mengumpulkan informasi tersebut walaupun tentu masih juga terbatas. Namun bila dibandingkan dengan kemampuan pribadi maka perpustakaan tentunya akan lebih memiliki kemampuan dalam hal pembelian maupun kapasitas simpan informasi tersebut. Karena itu pendidikan tidak bisa terlepas dari perpustakaan. Sebaliknya, perpustakaan tentunya selalu dikaitkan dengan pendidikan, baik pendidikan formal maupun pendidikan non formal yaitu sebagai sarana pendidikan sepanjang hayat (life-long learning). Ruben memperkuat hal ini dengan pernyataannya:"Libraries serve educational need either by directly assisting schools and colleges in the formal education process or by providing individuals with an opportunity to educate themselves" (Ruben, 2016). Selanjutnya Harbo dan Hansen mengatakan bahwa salah satu tugas perpustakaan adalah menyediakan pemustaka untuk akses ke banyak informasi, menawarkan pelatihan literasi informasi dan berusaha untuk menjadi bagian dari lingkungan belajar (Harbo \& Hansen, 2012).

Upaya pendidikan selama beberapa tahun telah melihat keterlibatan positif perpustakaan dalam pendidikan dengan menawarkan layanan rujukan, informasi, 
dan sumber pengajaran. Program bimbingan individu dan kelas pendidikan, selain akses ke kelompok orang-orang tertentu dengan keterbatasan jangkauan pendidikan sekarang banyak dilakukan oleh perpustakaan. Distribusi materi sumber daya informasi ke institusi, termasuk rumah sakit, penjara, panti jompo, pusat rehabilitasi dan kelompok dengan masalah terkait pendidikan dan remaja yang terlibat dalam kejahatan, pengangguran dan sejenisnya, membuat dampak yang terlihat pada pendidikan mereka (InfoScience Today, 2021).

\section{Kondisi perpustakaan Indonesia pada umumnya}

Di negara maju perpustakaan menjadi sebuah kebutuhan seperti halnya kebutuhan untuk konsumsi pangan yang di Indonesia disebut sembako (sembilan bahan pokok). Alasannya adalah jika sembako merupakan kebutuhan untuk makanan fisik, maka bacaan yang ada di perpustakaan merupakan makanan kejiwaan. Mungkin seseorang bisa memenuhi kebutuhan bacaan dengan cara membeli. Tapi itu sekedar bahan bacaan saja. Kita masih perlu menyelami apa sebetulnya yang tersedia di dalam perpustakaan dan dibutuhkan oleh masyarakat.

Di Indonesia kebutuhan terhadap perpustakaan tersebut masih belum seperti di negara maju. Beberapa kelompok masyarakat memang sudah sangat membutuhkan keberadaan perpustakaan. Ada perkiraan bahwa masyarakat yang merasakan perpustakaan itu penting bagi kehidupannya hanya berjumlah 7\% (Perpusnas, 2006). Namun demikian kebutuhan tersebut masih terbatas kepada bahan bacaan atau literatur. Misalnya, mahasiswa membutuhkan literatur untuk menyelesaikan tugas akhirnya. Jika perpustakaan tersebut diibaratkan sebuah kapal, maka kapal yang sangat besar tersebut hanya memuat sebagian kecil saja penumpang. Atau dengan kata lain sebuah perpustakaan yang besar hanya melayani sebagian kecil saja pemustaka. Padahal populasi yang mestinya dilayani tersebut jumlahnya sangat besar. Kapal besar tersebut diawaki oleh awak kapal yang kurang kompeten sehingga awak kapal tersebut tidak dapat memaksimalkan potensi yang ada pada kapal besar tersebut. Begitu juga halnya di perpustakaan. Pustakawan yang ditugaskan sebagian besar kurang kompeten, sehingga banyak fasilitas di perpustakaan besar tersebut tidak dapat dimanfaatkan secara maksimal. Ketiga, Kapal tersebut dipimpin oleh kapten kapal yang kurang kompeten sehingga arah dan jalannya kapal tersebut tidak selalu ke arah yang benar. Begitu juga perpustakaan besar yang dipimpin oleh seorang kepala perpustakaan yang tidak kompeten dan tidak kredibel. Tidak punya kemampuan kepemimpinan yang baik. Tidak memiliki pengetahuan dan keterampilan manajemen di bidang perpustakaan. Dengan kepala yang demikian tentu saja perpustakaan tersebut sulit diharapkan dapat membawa perpustakaannya ke arah tujuan perpustakaan yang benar. Dengan demikian perpustakaan yang besar dan dilengkapi fasilitas yang modern tersebut tidak dapat memberikan layanan yang sesuai dengan kebutuhan pemustakanya.

Sebagai contoh, mayoritas praktik perpustakaan di Indonesia sekarang ini adalah melayani peminjaman bahan perpustakaan. Kegiatan back office dari layanan ini adalah pengadaan/ pembelian bahan perpustakaan dan pengolahan bahan perpustakaan sampai bahan perpustakaan tersebut siap digunakan oleh pemustaka. Sampai di sini para pustakawan sering merasa sudah puas karena sudah memberikan layanan kepada pemustaka dengan baik. Dalam terminologi Kuhlthau layanan seperti ini justru berada pada level layanan (istilah Kuhlthau: level mediasi) terendah atau disebut "organizer". Dalam hal ini 
pustakawan hanya menyediakan koleksi yang dibutuhkan oleh pemustaka dan mengaturnya (mengolah sampai menempatkannya di rak dan melengkapinya dengan alat telusur yang baik) sehingga dapat ditemukan kembali dengan mudah. Dalam keadaan seperti ini maka interaksi pustakawan dengan pelanggannya sangat minim atau bahkan tidak terjadi interaksi sama sekali. Dan ini yang sebagian besar terjadi di perpustakaan di Indonesia.

\section{Kebutuhan informasi pemustaka}

Pemustaka menggunakan perpustakaan karena mereka memiliki kebutuhan akan informasi. Kebutuhan informasi tersebut timbul karena adanya kesenjangan pengetahuan yang dimiliki pemustaka dengan kebutuhan pemenuhan informasi yang diperlukannya dalam menyelesaikan sebuah persoalan. Sebagai contoh, dalam menyusun karya ilmiahnya seorang mahasiswa tingkat akhir merasa memiliki masalah karena pengetahuannya yang kurang atau tidak memadai dalam hal mencari dan menemukan informasi yang mereka butuhkan. Oleh sebab itu, timbul kebutuhan untuk memenuhi kekurangan pengetahuan tersebut. Kebutuhan informasi mengharuskan mahasiswa berinovasi mencari dan menemukan informasi yang relevan dengan kebutuhannya guna menyelesaikan masalahnya (Jamaluddin \& Tommeng, 2021). Sejalan dengan pernyataan Jamaluddin dan Tommeng, Zha dkk yang mengutip Marchionini (1995) menyatakan: "ketika individu mengalami kesenjangan kognitif yang mencegah mereka memahami situasi tertentu, mereka akan berusaha mencari informasi untuk mengubah keadaan pengetahuan mereka dan memenuhi kebutuhan informasi mereka" (Zha, Wang, Yan, Zhang, \& Zha, 2015).

\section{Lima level Mediasi Kuhlthau}

Di era teknologi informasi sekarang ini maka masyarakat (baca: pemustaka) dihadapkan kepada situasi yang sangat rumit. Katz mengatakan bahwa ada satu persoalan besar mengenai informasi saat ini yaitu informasi tersebut sangat banyak. Menurutnya bahkan tidak terhitung jumlah artikel, materi diskusi, buku dan bahkan program televisi yang diproduksi setiap hari. Orang menamakan kondisi ini sebagai “information overload” (Katz, 2002). Menurut Roth seorang ilmuwan atau peneliti menghabiskan kira-kira 20\%$25 \%$ waktu kerjanya hanya untuk mencari informasi (Roth, 1974). Dalam kondisi information overload tersebut maka untuk membantu pemustaka dalam hal pencarian informasi diperlukan layanan konsultasi.

Carol Collier Kuhlthau (Kuhlthau, 1994) memperkenalkan layanan informasi yang disebutnya sebagai intervensi kepada pemustaka yaitu merujuk secara khusus pada situasi di mana pustakawan berinteraksi langsung dengan siswa/ mahasiswa sebagai pemustaka yang sedang dalam proses mencari informasi. Menurut Kuhlthau ada dua layanan perpustakaan dasar di mana pustakawan profesional terlibat dalam intervensi tersebut yaitu referensi dan instruksi bibliografi. Layanan referensi adalah mediasi kepada pemustaka untuk membantu lokasi dan penggunaan sumber dan informasi. Mediasi seperti ini bisa mediasi sederhana, tetapi juga bisa mediasi yang panjang yang melibatkan proses pencarian informasi yang rumit dan sangat panjang. Sedangkan instruksi bibliografi adalah pendidikan kepada pemustaka dalam hal penggunaan alat belajar, sumber, dan konsep informasi dan strategi untuk menemukan dan menggunakan alat dan sumber informasi. 


\section{Intervensi/mediasiKuhlthau}

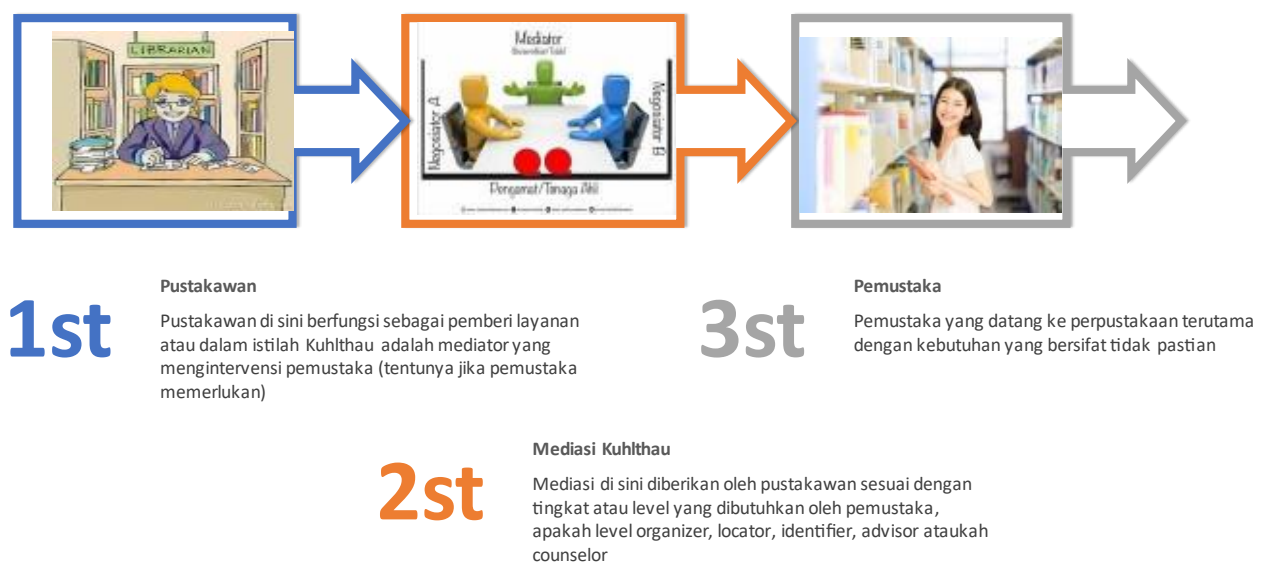

Gambar 1. Mediasi pustakawan kepada pemustaka menurut Kuhlthau (1994)

Konsep zona intervensi ditentukan oleh sifat masalah pemustaka dan tahapan proses pemustaka mengarah pada identifikasi tingkat mediasi dan pendidikan. Menurut Kuhlthau ada lima level mediasi yaitu: organizer (pengatur), locator (pencari lokasi), identifier (pengidentifikasi), advisor (penasihat), dan counselor (konselor). Jika pemustaka bisa bekerja sendiri dalam mencari intormasi maka pustakawan tidak perlu melakukan intervensi untuk memediasi pemustaka tersebut. Namun jika pemustaka tidak mampu melakukan pencarian sendiri maka kehadiran pustakawan untuk mengintervensi yaitu memediasi pemustaka sangat diperlukan.

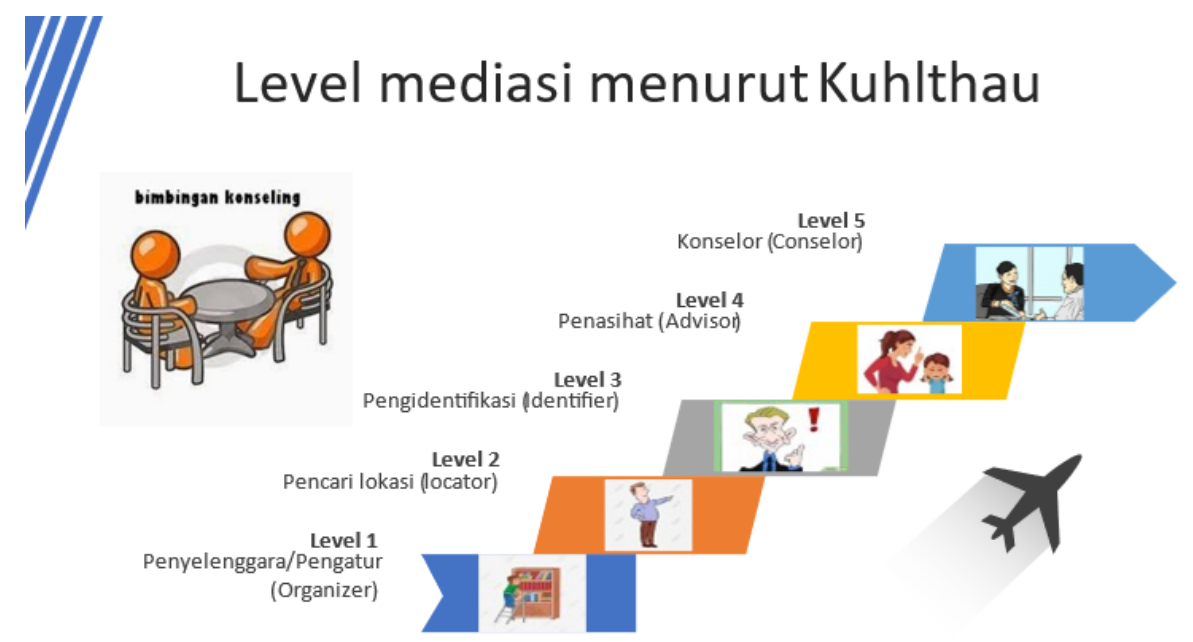

Gambar 2. Proses pencarian informasi dan intervensi

Selanjutnya Daland dan Hidle melengkapi penjelasan Kuhlthau pada masing-masing level mediasi tersebut sebagai berikut (Daland \& Hidle, 2016; Kuhlthau, 1994):

\section{Level 1: Pengatur (Organizer)}

- Pengatur adalah level 1 atau paling bawah, di mana tidak ada kontak langsung yang dibuat antara pustakawan dan pemustaka. Perpustakaan telah 
mengatur koleksi sedemikian rupa sehingga memungkinkan pemustaka dapat menggunakannya secara mandiri.

- Dalam hal ini, peran pustakawan hanya menyediakan koleksi sumber informasi yang terorganisir untuk akses independen.

- Peran pengatur, bagaimanapun, mendasari semua tingkat mediasi lainnya. Tanpa pengatur tidak akan ada akses ke sumber untuk belajar atau untuk tujuan lain. Tuntutan peran pengatur cenderung menuntut pustakawan lainnya untuk meningkatkan akses dan membimbing penggunaan bahan informasi yang tersedia.

Di Amerika level pekerjaan ini banyak dilakukan oleh asisten perpustakaan (library assistant) dan teknisi perpustakaan (library technician). McKay mengatakan bahwa di Amerika asisten perpustakaan (library assistant) mengerjakan pekerjaan klerikal. Pustakawan (librarian) dan teknisi perpustakaan (library assistant) mengawasi mereka. Tugas mereka termasuk mengatur koleksi, mengumpulkan denda untuk bahan perpustakaan yang terlambat dikembalikan atau hilang, memeriksa masuk dan keluar buku, DVD, dan bahan perpustakaan lainnya kepada pemustaka, dan melakukan shelving buku setelah digunakan oleh pemustaka. Asisten perpustakaan juga menjawab telepon atau mengatur berkas (file), serta melakukan tugas administrasi rutin lainnya. Mereka juga biasa disebut juru tulis perpustakaan, asisten teknis, dan asisten sirkulasi. Sedangkan teknisi perpustakaan (library technician) adalah paraprofesional yang bekerja di bawah pengawasan pustakawan. Tugas mereka bervariasi tergantung kepada ukuran fasilitas tempat mereka bekerja. Mereka dapat memesan dan mengatur koleksi perpustakaan, meminjamkannya kepada pemustaka, dan membantu menempatkan kembali koleksi itu ketika dikembalikan. Beberapa teknisi perpustakaan mengajari pelanggan cara menggunakan bahan perpustakaan (McKay, 2018).

\section{Level 2: Penunjuk Lokasi (locator)}

- Level ini mengandaikan bahwa ada satu jawaban yang benar untuk pertanyaan yang diajukan. Pertanyaan disampaikan di meja referensi, melalui email atau telepon, dan sering kali bersifat sederhana. Pertanyaannya mungkin berkisar dari alat manajemen referensi ke lokasi sebuah buku di perpustakaan.

- Level ini merupakan citra pustakawan paling stereotip yang dibayangkan banyak orang ketika mendengar kata perpustakaan. Sebuah pertanyaan ditanyakan di meja sirkulasi, dan pustakawan memberikan jawaban yang sederhana dan meyakinkan.

- Asumsi yang mendasari level ini adalah bahwa sistemnya pasti, pertanyaannya sederhana, dan ada satu jawaban yang benar

- Locator memiliki nilai yang terbatas ketika ada tidak jelasan, ambiguitas atau ketidakpastian

Pada level ini pustakawan sudah melakukan intervensi kepada pemustaka dalam bentuk menjawab pertanyaan yang simpel. Dalam terminologi Katz disebut sebagai menjawab pertanyaan referensi sederhana atau ready reference (Katz W. A., 2002). Dalam petunjuk teknis Jabatan Fungsional dan Angka Kreditnya pekerjaan ini masih dilakukan oleh pustakawan tingkat keterampilan (Perpusnas, 2015). Pustakawan pada tingkat ini masih setara dengan library assistant dan atau library technician di Amerika.

\section{Level 3: Pengidentifikasi (identifier)}

- Pengidentifikasi mengharapkan pertemuan antara pustakawan dengan pemustaka. Sejumlah sumber yang terkait dengan subjek yang sedang dibahas disajikan pada pertemuan tersebut.

- Sumber informasi ini direkomendasikan sebagai kumpulan informasi tanpa pemeringkatan. Sumber mungkin dari berbagai format dan kedalaman. 
- Biasanya, ketika pengguna datang ke koleksi dengan topik umum, mencari informasi dari sejumlah sumber, satu pencarian komprehensif disimpulkan dan "kumpulan" informasi diidentifikasi sebagai relevan dengan subjek tanpa ada saran tentang pendekatan atau saran apa pun dari melanjutkan dialog dengan mediator.

Level 3 yang disebut identifier ini sama dengan layanan menjawab pertanyaan specific-search question menurut William Katz (Katz W. A., 2002). Selanjutnya Katz mengatakan bahwa menjawab pertanyaan ini selalu dengan memberikan dokumen, daftar sitasi, buku, laporan dan bahkan sumber dari internet. Dalam petunjuk teknis jabatan fungsional pustakawan layanan seperti ini disebut dengan memberikan layanan penelusuran informasi kompleks dan dikerjakan oleh pustakawan ahli muda. Pendidikan untuk menduduki jabatan pustakawan tingkat keahlian ini adalah minimal sarjana di bidang ilmu perpustakaan atau sarjana non perpustakaan ditambah dengan diklat calon pustakawan tingkat keahlian (Perpusnas, 2015).

\section{Level 4: Penasihat (advisor)}

- Penasihat tidak hanya mengidentifikasi sumber pada suatu topik, tetapi juga merekomendasikan urutan penggunaan sumber, biasanya dari umum ke spesifik atau konkret ke abstrak, dengan beberapa pertimbangan untuk format dan kedalaman sumber. Pengguna mengajukan pertanyaan kompleks atau meminta informasi tentang suatu topik, dan penasihat merekomendasikan cara menavigasi informasi dengan menggunakan sumber a, kemudian sumber b, lalu sumber c, dan seterusnya.

- Penasihat tidak hanya orang yang memiliki pengetahuan tentang sumber informasi yang tersedia di perpustakaan, tetapi juga tahu bagaimana dan kapan informasi tersebut digunakan.
- Penasihat adalah orang yang memiliki pengetahuan tentang proses penelitian. Hanya dengan mengetahui dan memahami proses penelitian, pustakawan akan dapat mengetahui bagaimana menjelajahi lanskap informasi dan, yang lebih penting, bagaimana mengarahkan pemustaka ke arah yang benar.

Level mediasi ini dalam Katz disebut sebagai menjawab pertanyaan yang bersifat penelitian (research query). Katz mengatakan "a research is usually identified as that coming from an adult specialist who is seeking detailed information to assist in specific work", (Katz W. A., 2002). Sedangkan dalam petunjuk teknis jabatan fungsional pustakawan layanan ini disetarakan dengan layanan bimbingan penggunaan sumber referensi yang dikerjakan oleh pustakawan ahli madya (Perpusnas, 2015).

\section{Level 5: Konselor (counselor)}

- Di sini, asumsi yang mendasari adalah bahwa pemustaka sedang belajar dari informasi dalam proses yang konstruktif, saat pencarian informasi berlangsung. Tidak ada jawaban yang benar dan tidak ada urutan pasti untuk semua. Konselor membuat dialog dan mengharapkan pemustaka untuk kembali secara berkala untuk membangun kembali dialog berdasarkan konstruksi yang muncul

- Inilah situasi yang diinginkan jika atau ketika pustakawan dapat tetap berhubungan dengan pemustaka.

Level mediasi di sini sudah sangat kompleks. Pustakawan bahkan mestinya terlibat secara aktif dalam pekerjaan atau riset pemustaka yang dilayaninya. Pustakawan lebih tepat dikatakan sebagai mitra dari pemustaka. Contoh layanan yang seperti ini antara lain disebutkan dalam SKKNI sebagai menyusun tinjauan literatur (Menteri Ketenagakerjaan RI, 2019). Pekerjaan seperti ini tentu hanya bisa dilakukan oleh pustakawan ahli utama. Sebagai mitra dari 
pemustaka tingkat lanjut pustakawan tingkat ini juga dapat mengerjakan hal-hal seperti melakukan kajian interdisiplin, menyusun pemetaan

Kuhlthau menggambarkan mediasi tersebut dalam bentuk peta dalam hubungannya dengan level pendidikan atau kemampuan (baca: kompetensi) serta bentuk intervensi yang diberikan seperti yang tergambar pada peta berikut (Kuhlthau, 1994).

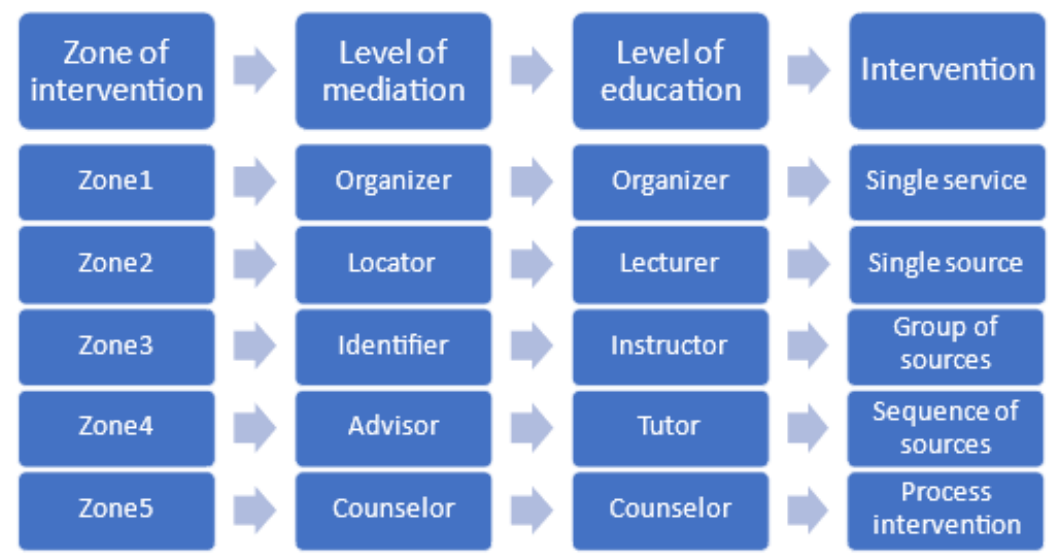

Gambar 3. Peta intervensi untuk mediasi menurut Kuhlthau (1994)

Dalam gambar tersebut di atas terlihat bahwa semakin tinggi level mediasi membutuhkan kompetensi yang semakin tinggi pula. Pada level mediasi terendah yaitu organizer atau pengatur pada zona 1 diperlukan level pendidikan (baca: kompetensi) pengatur dengan intervensi layanan tunggal. Sedangkan pada level mediasi tertinggi yaitu counselor atau konselor pada zona 5 memerlukan level pendidikan konselor yang memungkinkan orang tersebut memberi nasihat-nasihat dalam penemuan informasi yang dibutuhkan oleh pemakai (biasanya pemustaka level tinggi pula seperti mahasiswa tingkat doktoral atau mungkin juga seorang profesor).

Level kompetensi yang dibutuhkan untuk memberikan layanan atau intervensi mediasi menurut Kuhlthau ini dapat disandingkan dengan peta kompetensi sesuai dengan jenjang Kerangka Kualifikasi Nasional Indonesia KKNI seperti pada gambar 2 berikut.

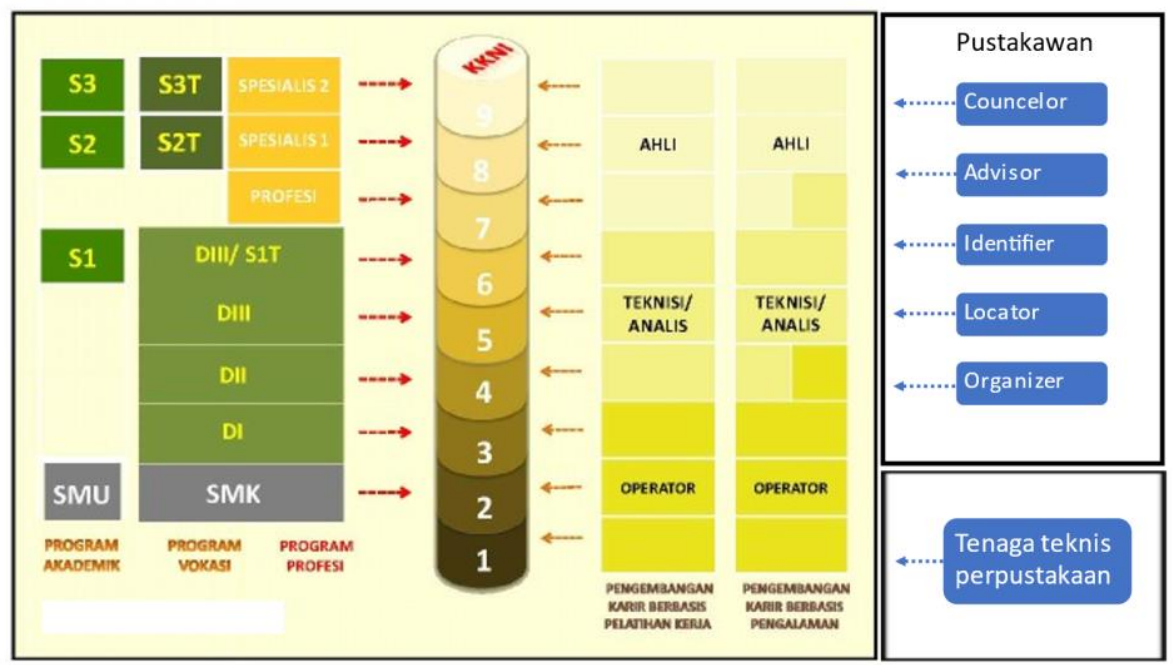

Gambar 4. Posisi level mediasi Kuhlthau terhadap Kerangka Kualifikasi Nasional Indonesia (KKNI) 
Pada gambar tersebut dapat dijelaskan bahwa level operator dapat dikerjakan oleh tenaga teknis perpustakaan, dalam hal ini bisa saja dengan tenaga tingkat SLTA. Kasus seperti ini bisa saja terjadi di perpustakaan desa yang masih sederhana. Sedangkan mediasi level organizer dan locator dapat dikerjakan oleh pustakawan tingkat keterampilan yaitu mulai dari pustakawan terampil, pustakawan mahir dan pustakawan penyedia. Pada level ini pustakawan memiliki pendidikan setidaknya level diploma bidang perpustakaan. Level mediasi identifier dapat dikerjakan oleh pustakawan tingkat keahlian dengan jabatan pustakawan ahli pertama sampai muda. Pada level ini pendidikan pustakawan hendaknya sudah pada level sarjana atau diploma IV. Level mediasi advisor dapat dikerjakan oleh pustakawan tingkat keahlian dengan jenjang pustakawan ahli madya. Tingkat pendidikan pustakawan pada level mediasi ini sebaiknya tingkat magister, atau jika sarjana maka harus dilengkapi dengan pengalaman yang panjang serta dengan pendidikan dan pelatihan yang cukup. Sedangkan level mediasi counselor dapat dikerjakan oleh pustakawan tingkat keahlian dengan jenjang pustakawan ahli utama. Dalam gambar tersebut juga jelas bahwa untuk dapat memberikan layanan dengan level mediasi counselor diperlukan pendidikan tingkat doktor. Kalaupun pendidikan pustakawan tersebut baru tingkat magister maka diperlukan pengalaman panjang atau dapat ditempuh dengan pendidikan non gelar yang dapat membekali pustakawan tersebut sehingga kemampuannya dapat disetarakan dengan pendidikan formal tingkat doktor.

\section{Layanan Perpustakaan Masa Kini dan Masa Depan}

Perpustakaan masa kini dan masa depan tidak bisa hanya melayani kebutuhan dasar pemustaka saja (dalam terminologi Kuhlthau disebut level mediasi Organizer), namun mereka harus juga bisa mengembangkan layananlayanan yang bersifat personal yaitu dengan level mediasi di atasnya. Dengan kemajuan teknologi informasi seperti sekarang ini layanan mediasi terendah atau level organizer bisa saja digantikan oleh mesin. Namun layanan dengan level mediasi di tingkat atas yang bersifat personal tidak mungkin digantikan oleh mesin. Layanan-layanan tersebut antara lain:

1. Bimbingan penelusuran informasi, yaitu literasi yang memungkinkan peserta didik dapat mengembangkan strategi pencarian dan pemanfaatan berbagai alat penemuan sumber informasi spesifik pada sebuah bidang ilmu. Di sini peserta didik diberi bimbingan cara-cara penggunaan basis data untuk menemukan sumber informasi terbaik guna menyelesaikan tugas-tugasnya yang terkait dengan pendidikan dan penelitian. Mahasiswa diarahkan agar dapat menetapkan kebutuhan informasinya dan dibimbing untuk membuat strategi pencarian yang efektif untuk menghasilkan serangkaian hasil penelusuran yang relevan.

\section{Bimbingan dalam menyusun} pertanyaan dan mengevaluasi informasi, yaitu literasi yang memungkinkan peserta didik untuk menganalisis, mengevaluasi, menafsirkan dan berpikir kritis tentang informasi. Bimbingan ini akan memberikan kesadaran akan tujuan, kekuatan dan kelemahan berbagai sumber informasi dan mempertimbangkan berbagai pertanyaan yang dapat digunakan untuk membantu mereka mengevaluasi informasi yang akan digunakan.

3. Bimbingan dalam menciptakan informasi, adalah literasi yang memungkinkan peserta didik untuk memadukan ide dan menangkap pengetahuan baru. Pustakawan memberikan beberapa tips untuk memulai menyusun informasi baru dengan membuat presentasi yang efektif dan memberikan kesempatan untuk menjelajahi berbagai perangkat lunak presentasi. 
4. Bimbingan dalam memahami informasi, adalah literasi yang memungkinkan peserta didik untuk menemukan makna dan menerapkan konteks. Pustakawan hendaknya dapat memberikan ikhtisar tentang manfaat, fungsi-fungsi, dan aplikasi sebuah buku elektronik. Dengan demikian diharapkan peserta didik dapat memanfaatkan koleksi buku yang tersedia secara daring (Online) dengan efisien dan efektif yaitu menggunakan fungsi-fungsi seperti menandai dan memberi catatan (anotasi).

5. Bimbingan penulisan daftar pustaka (referensi) adalah literasi yang memungkinkan peserta didik untuk menghargai pekerjaan orang lain, membangun analisis mereka sendiri atas pengetahuan yang ada. Pustakawan perlu memperkenalkan konsep plagiarisme dan memberikan panduan tentang cara mengutip secara efektif. Peserta didik juga perlu dikenalkan dengan aplikasi yang berguna untuk proses ini. Pustakawan perlu memberikan tip tentang bagaimana cara menghindari plagiarisme, mengenalkan tujuan referensi, dan memberikan kesempatan untuk berlatih referensi dalam gaya penulisan di lingkungan perguruan tingginya. Peserta didik perlu diberikan gambaran umum tentang perangkat lunak manajemen referensi (misalnya Mendeley) dan cara memanfaatkannya sebagai referensi dengan cepat dan efisien.

6. Bimbingan cara mengomunikasikan informasi, adalah literasi yang memungkinkan peserta didik mampu membuat ringkasan dan menyebarkan hasil pekerjaan dan gagasannya secara efisien melalui media-media yang tersedia, misalnya melalui blog, infografis, dan lain-lain.

7. Konsultasi informasi. Di negara maju tugas ini diberi nama readers adviser. Tugas dari konsultan informasi ini adalah memberikan bimbingan kepada mahasiswa baik strata satu (S1), dua (S2) maupun tiga (S3) dalam pelacakan informasi untuk kepentingan penelitiannya.

Agar layanan-layanan yang menjadi tuntutan pemangku kepentingan perpustakaan masa kini dapat disediakan dengan baik oleh perpustakaan, maka pustakawan yang menjadi motor utama perpustakaan selain memiliki kompetensi dasar kepustakawanan dia juga harus memiliki kemampuan lain seperti berikut:

1. Kemampuan dan penguasaan terhadap teknologi informasi dan komunikasi. Kemampuan ini tentunya akan mendukung tugas-tugas pustakawan yang semakin memerlukan teknologi informasi dan komunikasi. Pekerjaanpekerjaan perpustakaan yang sangat dasar pun saat ini memerlukan kompetensi TIK tersebut. Apalagi tugas-tugas terkait dengan repositori; bimbingan penggunaan berbagai aplikasi, seperti penggunaan aplikasi anti plagiarisme; penggunaan buku dan jurnal elektronik dan lain-lain sangat memerlukan pengetahuan dan kemampuan TIK.

2. Kemampuan melakukan penelitian/ pengkajian. Dalam hal ini kemampuan dan penguasaan metodologi penelitian sangat diperlukan, terutama untuk mendukung tugas-tugas pustakawan yang berhubungan dengan analisis informasi. Misalnya saja, pustakawan harus mampu meneliti tren arah penelitian di universitasnya, melakukan pemetaan bidang ilmu yang menjadi obyek penelitian para mahasiswa dan dosen di universitasnya. Kemampuan ini sangat diperlukan ketika pustakawan melakukan Collaborative Partnership dengan dosen dan atau profesor. Tidak sedikit pustakawan di perguruan tinggi yang terlibat penelitian bersama dengan dosen senior dan profesor. Bahkan banyak pustakawan yang menjadi nara sumber ketika profesor 
akan menerbitkan publikasi ilmiahnya. Banyak juga pengalaman pustakawan yang membantu profesor dalam mengajar (co-teaching), terutama terkait metodologi penelitian, dengan memberikan materi literasi informasi kepada mahasiswa.

3. Kemampuan berkomunikasi secara prima. Kemampuan berkomunikasi yang prima baik secara lisan (oral communications) maupun tulisan (written communications) harus dimiliki oleh pustakawan, terutama ketika harus menyampaikan informasi hasil penelitiannya kepada para pemangku kepentingan di universitasnya.

4. Kemampuan mengajar. Pustakawan harus dibekali dengan kemampuan mengajar, terutama dalam menyampaikan bimbingan dan juga dalam melakukan literasi informasi kepada peserta didik. Tanpa kemampuan mengajar yang baik walaupun pustakawan tersebut menguasai teknik-teknik literasi dia akan kesulitan dalam menyampaikannya kepada para peserta didik, apalagi peserta didik di lingkungan universitas.

5. Kemampuan menulis. Kemampuan ini sangat diperlukan dalam menyampaikan hasil-hasil kajiannya, terutama yang terkait dengan kebutuhan informasi para pemangku kepentingan perpustakaan universitasnya.

6. Kemampuan mengemas informasi. Produk-produk dan jasa perpustakaan seperti abstrak, indeks, tinjauan literatur, pathfinder, panduan literatur dan informasi sekunder lainnya akan sangat memerlukan kemampuan ini.

7. Kemampuan menyusun rencana strategis. Artinya pustakawan harus mampu menyusun rencana strategis perpustakaannya dalam menyiapkan layanan yang akan diberikan kepada para pemangku kepentingannya. Setiap kelompok pemangku kepentingan tersebut tentu memiliki kebutuhan informasi yang berbeda dan harus dipenuhi oleh pustakawan di perpustakaan perguruan tinggi.

8. Kemampuan mengelola informasi. Mengelola informasi sebagai pengetahuan (knowledge) dan memanfaatkannya secara optimal untuk menghasilkan publikasi ilmiah bermutu dan terbaru.

9. Kemampuan melakukan telaah sistem kepustakawanan. Kegiatan itu dapat diartikan pustakawan sebagai pengendali mutu dalam operasional perpustakaan, membantu kepala perpustakaan dalam monitoring dan evaluasi manajemen perpustakaan, agar perpustakaan dapat terus berkembang maju (continuous improvement) memenuhi tuntutan para pemangku kepentingan.

\section{Penutup}

Sesuai dengan level mediasi Kuhlthau, maka pustakawan hendaknya dalam bekerja harus menyesuaikan diri dengan tingkatan kompetensinya. Seorang pustakawan dengan jenjang pustakawan utama atau yang bergelar doktor hendaknya mengerjakan pekerjaan dengan level pekerjaan pada tingkatnya. Perpustakaan yang mempekerjakan pustakawan utama atau pustakawan yang bergelar doktor dengan pekerjaanpekerjaan level di bawahnya, maka perpustakaan tersebut dapat dikatakan merugi karena mempekerjakan tenaga yang over qualified. Kondisi ini dapat berdampak kepada kebijakan pemerintah dalam mengatur penjenjangan pustakawan di mana pekerjaan-pekerjaan pustakawan yang tinggi sekalipun dapat dikerjakan oleh pustakawan dengan jenjang yang lebih rendah. Dengan demikian dapat memunculkan kesimpulan bahwa jabatan pustakawan tidak perlu jenjang yang tinggi karena jenjang rendah pun dapat menyelesaikannya. 


\section{Daftar Pustaka}

Daland, H. D., \& Hidle, K.-M. (2016). New Roles for Research Librarians Meeting The Expectations For Research Support. Cambridge: Chandos Publishing.

Harbo, K., \& Hansen, T. V. (2012). Getting to Know Library Users' Needs Experimental Ways to User-centred Library Innovation. Liber Quarterly, 21(3/4), 367385.

InfoScience Today. (2021). The role of libraries in education. Diambil kembali dari InfoScience Today.com:

https://www.infosciencetoday.org/libraryscience/the-role-of-libraries-ineducation.html

Jamaluddin, \& Tommeng, L. (2021). Hubungan Antara Perilaku Pencarian Informasi Terhadap Perilaku Inovatif Mahasiswa di UPT Perpustakaan Universitas Hasanuddin. Media Pustakawan, 28(1), 2636. Diambil kembali dari https://ejournal.perpusnas.go.id/mp/articl e/view/1102/pdf

Katz, W. A. (2002). Introduction to reference work: Basic information services (Volume I). New York: McGraw-Hill.

Katz, W. A. (2002). Introduction to reference work: reference services and reference processes (volume II) (8th ed., Vol. II). New York: McGraw-Hill.

Kuhlthau, C. C. (1994). Students and the Information Search Process: Zones of
Intervention for Librarians. Advances in Librarianship, 18, 57-72.

McKay, D. R. (2018, March 20). Library Job. Dipetik May 26, 2021, dari The Balance Career:

https://www.thebalancecareers.com/librar y-careers-525868

Menteri Ketenagakerjaan RI. (2019). Keputusan Menteri Ketenagakerjaan RI: Penerapan Standar Kompetensi Kerja Nasional Indonesia Kategori Kesenian, Hiburan dan Rekreasi Golongan Pokok Perpustakaan, Arsip, Museum, dan Kegiatan Budaya Lainnya. Bidang Perpustakaan. Jakarta: Kementerian Ketenagakerjaan Republik Indonesia.

Perpusnas. (2006). Naskah akademik Rancangan Undang-undang Perpustakaan. Jakarta: Perpustakaan Nasional RI.

Perpusnas. (2015). Peraturan Kepala Perpustakaan Nasional Republik Indonesia Nomor 11 Tabun 2015 tentang Petunjuk Teknis Jabatan Fungsional Pustakawan dan Angka Kreditnya. Jakarta: Perpusnas RI.

Roth, D. L. (1974). The needs of library users. Unesco Bull. Libr., 28(2), 92-94.

Ruben, R. E. (2016). Foundation of Library and Information Science (Fourth ed.). Chicago: American Library Association.

Zha, X., Wang, W., Yan, Y., Zhang, J., \& Zha, D. (2015). Understanding information seeking in digital libraries:. Aslib Journal of Information Management, 67(6), 715-734. 